\section{Assessment of Marginal Bone Loss around Platform- Matched and Platform-Switched Implants - A Prospective Study}

Newton Sesma ${ }^{1}$, Carlos Garaicoa-Pazmino², Piero R. Zanardi ${ }^{1}$, Eliseo P. Chun $^{3}$, Dalva Cruz Laganá ${ }^{1}$

\author{
'Department of Prosthodontics, \\ Dental School, USP - Universidade \\ de São Paulo, SP, São Paulo, Brazil \\ ${ }^{2}$ Department of Periodontics \\ and Oral Medicine, University of \\ Michigan School of Dentistry, \\ Ann Arbor, Ml, USA \\ ${ }^{3}$ Department of Dental Materials \\ and Prosthodontics, Institute of \\ Science and Technology, UNESP \\ - Univ Estadual de São Paulo, São \\ José dos Campos, SP, Brazil
}

Correspondence: Newton Sesma, Faculdade de Odontologia, USP, Departamento de Prótese, Avenida Professor Lineu Prestes, 2227, 05508-000 São Paulo, Brasil. Tel: +55-11-3091-7888. e-mail address: sesma@usp.br

Key Words: dental implant, platform switching, marginal bone loss, digital radiography

\section{Introduction}

Modern clinicians often choose implant therapy as the first treatment option to replace missing teeth. Morphological bone changes should be expected after tooth extraction and implant placement that may result in challenging situations and compromise aesthetics (1). Early identification of surgical and prosthetic factors that induce detrimental effects upon the peri-implant tissues becomes crucial in routine procedures.

Peri-implant marginal bone loss (MBL) at the shoulderabutment connection has been associated with biological complications that may trigger inflammatory events and further progressing to peri-implant diseases. Peri-implant tissue adaptations may result from the presence of biological width following implant rehabilitation, bacterial colonization at the implant shoulder-abutment interface and stress concentration at the implant shoulder during function $(2,3)$.

Platform switching advocates the concept of using smaller diameter abutments than the implant platform in order to reduce the amount of peri-implant MBL (4). The horizontal inward repositioning of the implantabutment interface was responsible for confining the bone remodeling away from the outer edge of the implant and thus preserving the peri-implant tissues. Numerous studies evaluating the clinical outcomes of platform-switching have shown long-term promising results $(5,6)$. Moreover, studies including different diameter of implants (7), implant surfaces (8) and abutment connections (9) have been addressed as possible confounding factors to consider when selecting an implant system for platform switching.

To the authors' knowledge few studies examined the implant connection as a potential variable with a biological impact, rather than a mechanical effect upon MBL around platform-switched implants. Thus, this prospective study aimed to evaluate the effect of platform switching on implants with internal hexagonal connection. The work hypothesis was that implants with a platform-matched abutment have greater MBL than implants with a platformswitched abutment.

\section{Material and Methods Subject Selection}

This study was approved by the Ethics Committee of the Dental School of the Universidade de São Paulo (Opinion 401 778). Patients undergoing dental care at the Dental Center of Military Police of São Paulo (COdont) and at Center of Excellence for Prosthodontics and Implant Dentistry (CEPI) of the Dental School, University of São Paulo were enrolled, treated and followed up within a 15-month interval. For each group, 18 patients were initially included, based on a statistical sample size for 
a bone loss statistical difference of $0.5 \mathrm{~mm}$ after 1 year of loading, $p=0.05,0.5 \mathrm{~mm}$ standard deviation and $85 \%$ of statistical power. Furthermore, 2 patients were added to each group considering a possible dropout of $10 \%$. Patients with healed edentulous non-grafted sites in the posterior mandible requiring single implant restorations were eligible for the present study. Exclusion criteria were as follows: patients with uncontrolled systemic diseases, pregnant or lactating women, active periodontal disease, smoking, signs of parafunctional activity, history of oral cancer which requires radiation therapy and patient taking medications known to alter bone metabolism (i.e. bisphosphonates).

\section{Surgical and Prosthetic Protocols}

Virtual implant software was used (Dental Slice ${ }^{\circledR}$, Bioparts Prototipagem Biomédica, Brasilia, DF, Brazil) to enable a three-dimensional bone reconstruction, allowing the diameter, length and position of the implants to be planned with greater precision. Patients were randomly categorized into two main groups: $4 \mathrm{~mm}$ diameter platform-matched abutments (control group) on a 4 mm diameter internal hexagonal implant (Conect $A R^{\circledR}$, Conexão Sistema de Prótese, Arujá, Brazil) and $4 \mathrm{~mm}$ diameter platform-switched abutments (test group) on 5 -mm diameter internal hexagonal implants. All implants had the same cylindrical-tapered design and acid-etched treated surface.

Under local anesthesia, the surgical sites were prepared with sequential drills under constant irrigation according to the manufacturer's recommendations and performed by the same surgeon (NS). Besides the quality and quantity of bone support, the mesiodistal and buccolingual inclination of the implants were chosen by the functional and aesthetic requirements. All implants were placed in native bone at crestal bone level in a prosthetically driven position and healing abutments were simultaneously installed. After implant placement, patients were under clinical and radiographic observation every four months during the whole study. Implants were excluded from the present study if probing depths $\geq 4 \mathrm{~mm}$ were associated with radiographic bone loss beyond the bone physiological remodeling, pain, mobility, bleeding on probing and/or suppuration (10-12).

The prosthetic phase was performed 3 months after implant installation. The choice of components, prosthetic planning, installation of abutments, clinical and radiographic evidence of copings and veneering was performed by the same professional (NS). Screwed porcelain-fused-to-metal crowns were used to restore implants and torqued following the manufacturers' instructions.

\section{Radiographic Assessment}

Standardized periapical radiographs were obtained at the time of implant placement (T0), at implant loading (T1) and 1-year after implant loading (T2). Periapical radiographs were digitized with a scanner (Scaner Vita Scan Combi Plus, Durr Dental AG, Bietigheim-Bissingen, Germany). A computer software (DBSWIN 5.2.0, Durr Dental) was used to calculate the distance between the outer edges of the implant platform to the first vertically (VDIB) and horizontally (hDIB) visible crestal bone ; and the bone loss area (BLa) circumscribed between vDIB and hDIB as depicted in Figure 1. All calculations were performed by the same calibrated examiner (NS) at all time points.

\section{Statistical Analysis}

Non-parametric Mann-Whitney and Student's t-test were used to verify the inter-group differences among the averages of $\mathrm{VMBL}, \mathrm{hMBL}$ and BLa and to compare mean differences between variables at all time intervals (T1-T0, T2-T1, T2-T0), the Wilcoxon and paired t-test were used to verify differences between the experimental times. A possible association between time and bone loss was evaluated by linear regression.

\section{Results}

Forty patients were enrolled and classified according to their implant platform-abutment relationship. No implant was lost nor presented signs of peri-implant disease. Table 1 shows mean and standard deviation values between groups with respect of $\mathrm{VMBL}, \mathrm{hMBL}$ and $\mathrm{BLa}$, at T0, T1 and T2. Linear regression graphs indicate a significant progressive increase of vertical and horizontal bone loss

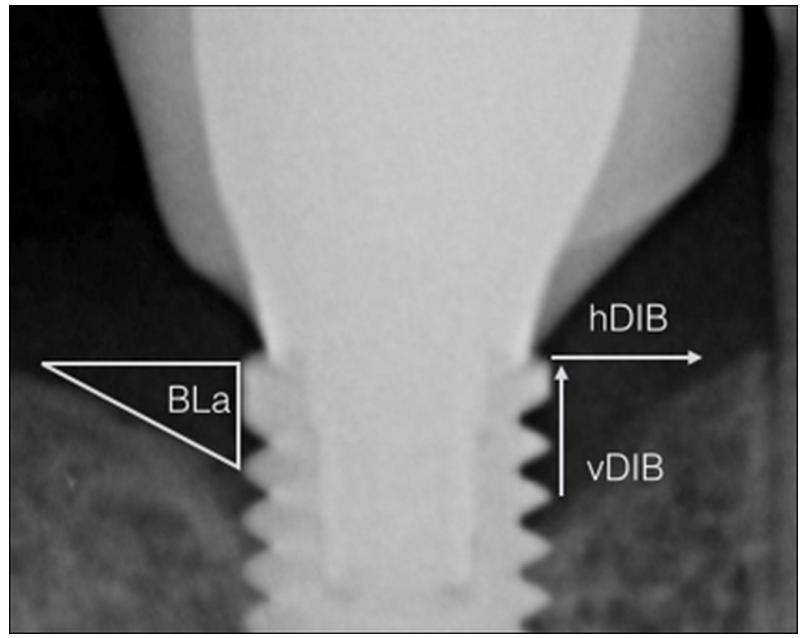

Figure 1. Software-assisted assessment of the distance between the outer edges of the implant platform to the first visible crestal bone vertically (vDIB) and horizontally (hDIB); and the bone loss area (BLa) circumscribed between vDIB and hDIB. 
(Figs. 2 and 3) and average bone loss area (Fig. 4) from the implant shoulder to bone crest in both groups, as a result of the physiological bone remodeling after implant placement $(p<0.05)$.

Peri-implant MBL comparisons between platformmatched (control) and platform-switched implants (test) are in Table 2. Changes in hMBL and vMBL between implant placement and implant loading (T1-T0) were significantly reduced $(p<0.05)$, but no significant difference was found regarding the BLa $(p>0.05)$. Comparisons between periimplant MBL at implant loading and 1 -year after functional loading (T2-T1) exhibited significant differences in $\mathrm{hMBL}$ and BLa $(p<0.05)$, but not in VMBL $(p=0.89)$. Finally, bone changes between implant placement and 1-year after functional loading (T2-T0) showed a significantly higher $\mathrm{MBL}$ for platform-matched abutments compared to

Table 1. Mean marginal bone level and standard deviation values between platformswitched abutments (test group) and platform-matched abutments (control group) with respect of vMBL, hMBL and BLa at 3 different time points (T0. T1 and T2)

\begin{tabular}{|c|c|c|c|c|}
\hline Variable & Group & T0 & $\mathrm{T} 1$ & $\mathrm{~T} 2$ \\
\hline Vertical & G1 & $0.20 \pm 0.13$ & $0.79 \pm 0.18$ & $1.18 \pm 0.21$ \\
\hline \multirow[t]{2}{*}{$(\mathrm{mm})$} & G2 & $0.34 \pm 0.16$ & $0.83 \pm 0.19$ & $1.15 \pm 0.24$ \\
\hline & & $<0.05^{*}(\mathrm{MW})$ & $>0.05$ (MW) & $>0.05$ (MW) \\
\hline Horizontal & G1 & $0.29 \pm 0.15$ & $0.92 \pm 0.13$ & $1.33 \pm 0.19$ \\
\hline \multirow[t]{2}{*}{$(\mathrm{mm})$} & G2 & $0.32 \pm 0.12$ & $0.85 \pm 0.18$ & $1.16 \pm 0.25$ \\
\hline & & $>0.05$ (t test) & $>0.05$ (MW) & $>0.05$ ( $\mathrm{t}$ test) \\
\hline Area & G1 & $0.03 \pm 0.02$ & $0.37 \pm 0.12$ & $0.80 \pm 0.22$ \\
\hline \multirow[t]{2}{*}{$\left(\mathrm{mm}^{2}\right)$} & G2 & $0.06 \pm 0.04$ & $0.37 \pm 0.15$ & $0.69 \pm 0.28$ \\
\hline & & $<0.05^{*}(\mathrm{MW})$ & $<0.05$ (t test) & $<0.05$ ( $t$ test $)$ \\
\hline
\end{tabular}

MW= Mann-Whitney. *Intergroup significant difference ( $\alpha$ 5\%) between group 1 and 2.

Table 2. Peri-implant marginal bone changes in vertical and horizontal directions and area at different time interval (T1-T0. T2-T1 and T2-T0)

\begin{tabular}{lcccc}
\hline \multirow{2}{*}{ Variable } & Group & \multicolumn{3}{c}{ Time intervals } \\
\cline { 3 - 5 } & & $\mathrm{T} 1-\mathrm{T} 0$ & $\mathrm{~T} 2-\mathrm{T} 1$ & $\mathrm{~T} 2-\mathrm{T} 0$ \\
\hline Vertical & $\mathrm{G} 1$ & $0.59 \pm 0.15$ & $0.40 \pm 0.19 \neq$ & $0.99 \pm 0.21$ \\
$(\mathrm{~mm})$ & $\mathrm{G} 2$ & $0.50 \pm 0.15$ & $0.32 \pm 0.14 \neq$ & $0.82 \pm 0.20$ \\
& & $\mathrm{p}<0.05^{*}(\mathrm{MW})$ & $\mathrm{p}=0.89(\mathrm{MW})$ & $\mathrm{p}<0.05^{*}$ (t test) \\
Horizontal & $\mathrm{G} 1$ & $0.64 \pm 0.16$ & $0.41 \pm 0.20 \ddagger$ & $1.04 \pm 0.18$ \\
$(\mathrm{~mm})$ & $\mathrm{G} 2$ & $0.53 \pm 0.15$ & $0.31 \pm 0.15 \ddagger$ & $0.84 \pm 0.18$ \\
& & $\mathrm{p}<0.05^{*}(\mathrm{MW})$ & $\mathrm{p}<0.05^{*}(\mathrm{MW})$ & $\mathrm{p}<0.05^{*}$ (MW) \\
Area & $\mathrm{G} 1$ & $0.34 \pm 0.11$ & $0.43 \pm 0.20 \ddagger$ & $0.77 \pm 0.22$ \\
$\left(\mathrm{~mm}{ }^{2}\right)$ & $\mathrm{G} 2$ & $0.31 \pm 0.13$ & $0.32 \pm 0.18$ & $0.63 \pm 0.26$ \\
& & $\mathrm{p}>0.05$ (t test) & $\mathrm{p}<0.05^{*}$ (t test) & $\mathrm{p}<0.05^{*}$ (t test) \\
\hline
\end{tabular}

MW =Mann-Whitney. $¥$ Significant difference among time intervals (T1-T0 vs. T2-T1) at alpha level 5\%. * Significant difference between groups 1 and 2 at alpha level 5\% platform-switched in $\mathrm{hMBL}$, vMBL and BLa.

\section{Discussion}

The biologic width around osseointegrated implants has been extensively investigated $(13,14)$. Effects of platform switching in limiting the peri-implant MBL have been discussed in both prospective and longitudinal human studies $(3,9)$ and displayed long-term stability $(15,16)$. Conversely, numerous studies have also reported results rejecting the platform-switching concept. After 2 years, Crespi et al. (17) reported a mean vMBL of $0.73 \mathrm{~mm}$ and $0.78 \mathrm{~mm}$ around matched and mismatched abutments, respectively (17). Similarly, Enkling et al. (18) showed mean vMBL of $0.58 \mathrm{~mm}$ and $0.53 \mathrm{~mm}$ around non-platform witching and platform switching after 12 months.

Implants restored according to the platform-switching concept could experience different patterns of MBL when compared to implants with platform-matched abutments. To avoid heterogeneity in the interpretation of the data, all patients underwent the same treatment modality in a similar way to a previous study (19). The choice of the statistical power was settled before the clinical phase to avoid underpowering or overpowering. Between these two extremes, the statistical power of $85 \%$ reduced the chance of Type II error and the number of subjects, and assured the viability of the statistical analysis. This study revealed no significant differences between Group 1 and 2 in terms of mean vMBL and $\mathrm{hMBL}$ at $\mathrm{T} 1$ and T2. The only meaningful differences were observed when considering BLa. These results showed that both implants with matched and switched platform presented progressive bone loss. However, comparisons between different time intervals may be crucial to accurately confirm the concept of platformswitching (15). From the time point of prosthesis installation, which created a horizontal inward mismatch for the test group, to 1 year follow-up (T2-T1), a significant $h M B L$ and BLa reduction occurred around switched platform implants and the linear regression showed a trend of higher MBL around matched platform implants over time.

A physiological bone remodeling around dental implants may occur after 


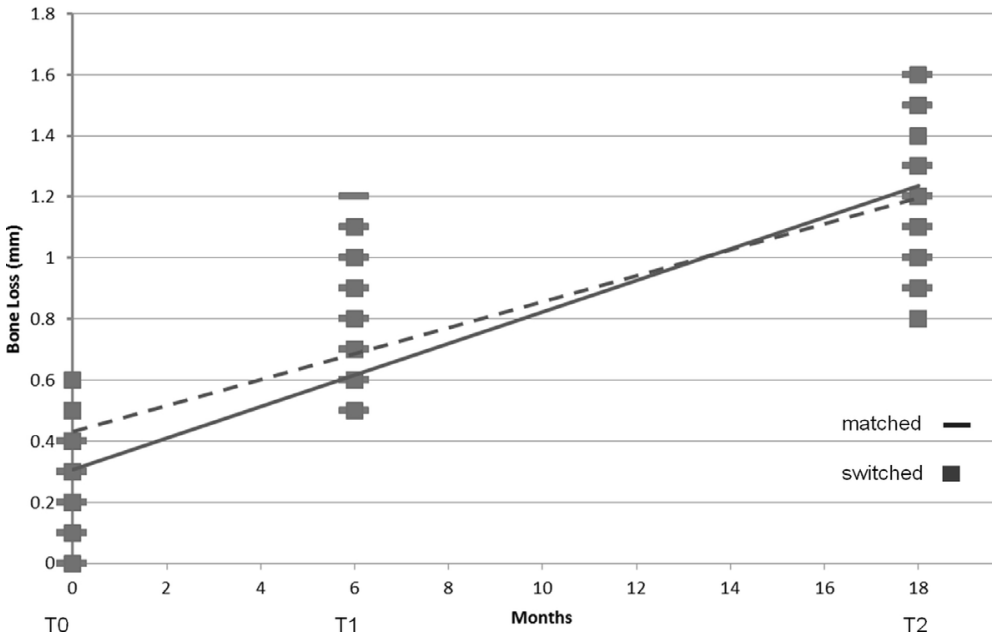

Figure 2. Linear regression indicating a significant progressive increase of vertical bone loss for matched and switched abutments over 18 months.

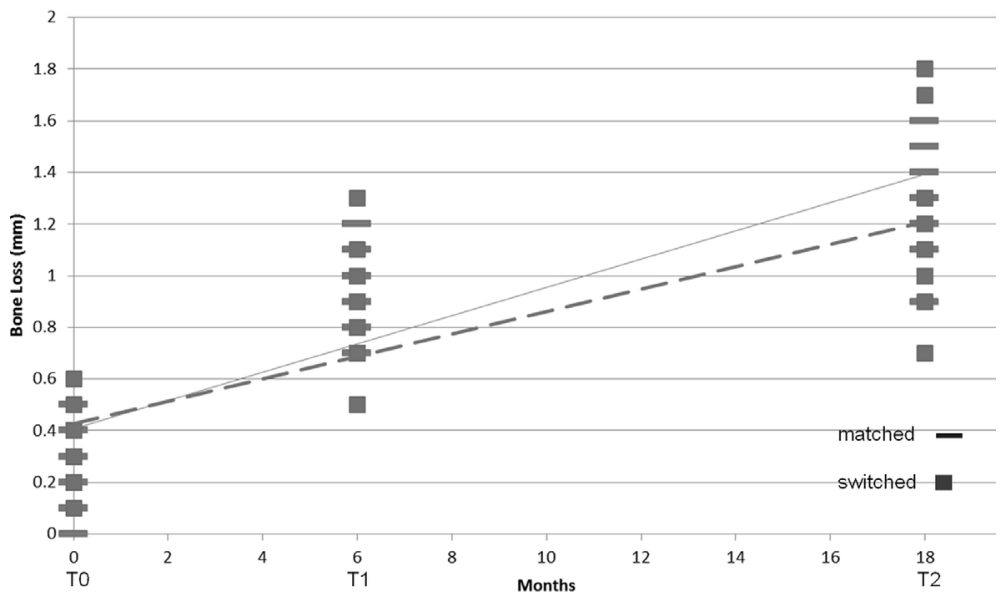

Figure 3. Linear regression indicating a significant progressive increase of horizontal bone loss for matched and switched abutments over 18 months.

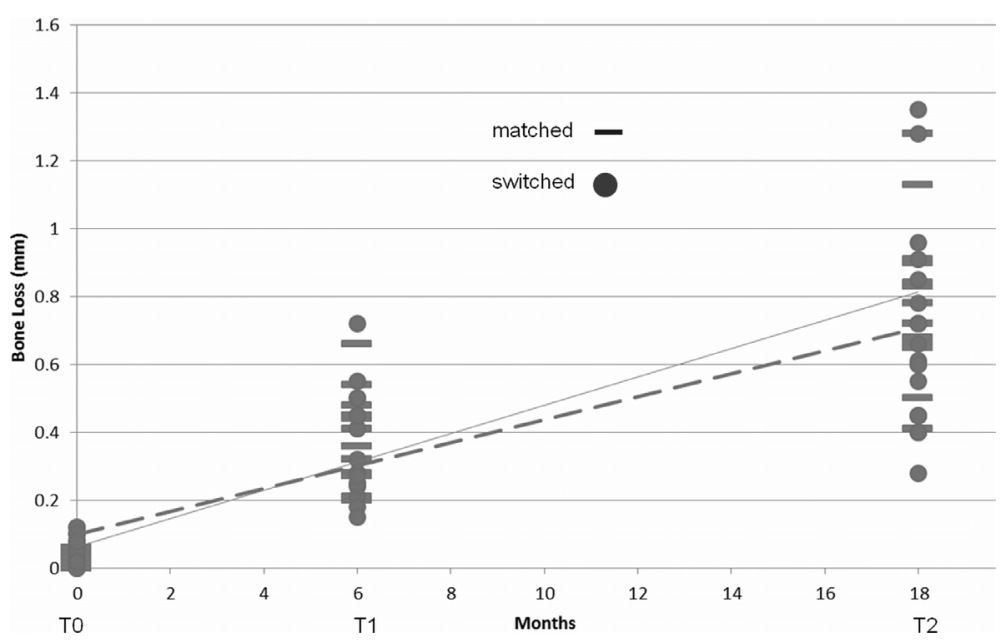

Figure 4. Linear regression indicating a significant progressive increase of bone loss area for matched and switched abutments over 18 months. the connection of prosthetic components and the induction of mechanical loading. This shows up because of the biological width after the implant exposure to the oral cavity. Such findings are clinically relevant when considered the interproximal distances between implants or to an adjacent tooth. Tarnow et al. $(20,21)$ reported a minimal distance of $3.4 \mathrm{~mm}$ between implants in order to avoid soft tissue changes and 1.5 $\mathrm{mm}$ between adjacent teeth. The benefits of platform switching in a clinical setting could be advantageous as long as limited edentulous spaces are present and narrow implants are not considered, especially in the esthetic zone.

Furthermore, the MBL extension seems to be dependent upon a myriad of factors including implant collar design, apicocoronal implant location during placement and soft tissue thickness. Special attention to the soft tissue thickness indicated a potential key role in preventing peri-implant MBL. Linkevicius et al. (22) reported a mean MBL of $1.17 \mathrm{~mm}$ in thin soft tissues $(<2 \mathrm{~mm})$ and $0.21 \mathrm{~mm}$ in thick tissues $(\geq 2 \mathrm{~mm})$ on abutment mismatch after 1-year followup. Thin soft tissues $(<2 \mathrm{~mm})$ may prove detrimental upon peri-implant MBL despite the advised use of platform-switching (22). Bacterial colonization could also induce a detrimental effect on the long-term stability around dental implants (23). This may occur as consequence of leakage at the implant-abutment interface or as a result of contamination during implant placement and thus inhibiting the possible effects of platform-switching $(17,18,24)$.

Protein biomarkers and microbial profile from oral fluids could be valuable diagnostic and prognostic tools in the assessment of disease activity around dental implants (25). Further clinical studies using biomarkers to monitor the physiological bone remodeling and changes in the microbiome in periimplant sulcus are still required to help clinicians to make safe and predictable decisions in their clinical practice.

Within the limitations of the present study, it may be concluded that platformswitchings have a positive short-term impact upon the amount of marginal bone loss 
around loaded implants with internal hexagon connection. Further long-term longitudinal studies are required to validate this concept.

\section{Resumo}

0 objetivo do presente estudo foi realizar uma avaliação radiográfica assistida por computador do efeito da plataforma reduzida sobre a perda óssea marginal (MBL) ao redor de implantes. Quarenta pacientes que necessitavam um implante em mandibulas parcialmente edêntulas não enxertadas foram selecionados e divididos em implantes que receberam pilares de plataforma igualada (grupo controle) ou implantes com pilares de plataforma reduzida (grupo teste). Radiografias periapicais digitais padronizadas foram realizadas no momento da instalação do implante (T0), carregamento do implante (T1) e 1 ano após carregamento funcional (T2). Avaliação radiográfica assistida por computador da MBL horizontal, vertical e mudanças de área foi realizada e comparada entre os intervalos de tempo (T1-T0, T2-T1 e T2-T0). A média radiográfica da MBL horizontal ( $h M B L$ ) e da MBL vertical (vMBL) do momento da instalação do implante até 1 ano após carregamento (T2-T0) foram significativamente aumentadas ao redor dos pilares de plataforma igualada quando comparado com os pilares de plataforma reduzida $(1,04 \mathrm{~mm}$ vs $0,84 \mathrm{~mm}, p<0,05)$ e $(0,99 \mathrm{~mm}$ vs $0,82, \mathrm{~mm}, \mathrm{p}<0,05)$, respectivamente. Além disso, a área de perda óssea (BLa) foi maior $\left(0,77 \mathrm{~mm}^{2}\right.$ vs $\left.0,63 \mathrm{~mm}^{2} ; p<0,05\right)$ para plataforma igualada comparada com pilares de plataforma reduzida. Plataforma reduzida tem um impacto positivo na remodelação óssea após carregamento de implantes com conexão interna hexagonal.

\section{References}

1. Paolantonio $M$, Dolci $M$, Scarano A, d'Archivio D, Di Placido G, Tumini V, et al.. Immediate implantation in fresh extraction sockets. A controlled clinical and histological study in man. J Periodontol 2001;72:15601571.

2. Atieh MA, Ibrahim HM, Atieh AH. Platform switching for marginal bone preservation around dental implants: a systematic review and meta-analysis. J Periodontol 2010;81:1350-1366.

3. Wagenberg B, Froum SJ. Prospective study of 94 platform-switched implants observed from 1992 to 2006. Int J Periodontics Restorative Dent 2010;30:9-17.

4. Lazzara RJ, Porter SS. Platform switching: a new concept in implant dentistry for controlling postrestorative crestal bone levels. Int J Periodontics Restorative Dent 2006;26:9-17.

5. Fickl S, Zuhr O, Stein JM, Hurzeler MB. Peri-implant bone level around implants with platform-switched abutments. Int J Oral Maxillofac Implants 2010;25:577-581.

6. Prosper L, Redaelli S, Pasi M, Zaron F, Radaelli G, Gherlone EF. A randomized prospective multicenter trial evaluating the platformswitching technique for the prevention of postrestorative crestal bone loss. Int J Oral Maxillofac Implants 2009;24:299-308.

7. Canullo $L$, Fedele GR, lannello $G$, Jepsen $S$. Platform switching and marginal bone-level alterations: the results of a randomized-controlled trial. Clin Oral Implants Res 2010;21:115-121.

8. Kielbassa AM, Martinez de Fuentes $R$, Goldstein M, Arnhart C, Barlattani $A$, Jackowski J, et al.. Randomized controlled trial comparing a variablethread novel tapered and a standard tapered implant: interim one-year results. J Prosthet Dent 2009;101:293-305.

9. De Angelis N, Nevins ML, Camelo MC, Ono Y, Campailla M, Benedicenti S. Platform switching versus conventional technique: a randomized controlled clinical trial. Int J Periodontics Restorative Dent 2014:34 Suppl 3:s75-79.

10. Weber HP, Crohin CC, Fiorellini JP. A 5-year prospective clinical and radiographic study of non-submerged dental implants. Clin Oral Implants Res 2000;11:144-153.

11. Mangano C, Mangano F, Shibli JA, Ricci M, Sammons RL, Figliuzzi M. Morse taper connection implants supporting "planned" maxillary and mandibular bar-retained overdentures: a 5-year prospective multicenter study. Clin Oral Implants Res 2011;22:1117-1124.

12. American Academy of Periodontolgy. Peri-implant mucositis and periimplantitis: a current understanding of their diagnoses and clinical implications. J Periodontol 2013;84:436-443.

13. Berglundh T, Lindhe J. Dimension of the periimplant mucosa. Biological width revisited. J Clin Periodontol 1996;23:971-973.

14. Cochran DL, Obrecht $M$, Weber $K$, Dard M, Bosshardt D, Higginbottom $\mathrm{FL}$, et al.. Biologic width adjacent to loaded implants with machined and rough collars in the dog. Int J Periodontics Restorative Dent 2014;34:773-779.

15. Schwarz F, Alcoforado G, Nelson K, Schaer A, Taylor T, Beuer F, et al.. Impact of implant-abutment connection, positioning of the machined collar/microgap, and platform switching on crestal bone level changes. Camlog Foundation Consensus Report. Clin Oral Implants Res 2014;25:1301-1303.

16. Fernandez-Formoso N, Rilo B, Mora MJ, Martinez-Silva I, Diaz-Afonso AM. Radiographic evaluation of marginal bone maintenance around tissue level implant and bone level implant: a randomised controlled trial. A 1-year follow-up. J Oral Rehabil 2012;39:830-837.

17. Crespi $R$, Cappare $P$, Gherlone E. Radiographic evaluation of marginal bone levels around platform-switched and non-platform-switched implants used in an immediate loading protocol. Int J Oral Maxillofac Implants 2009;24:920-926

18. Enkling N, Johren P, Klimberg V, Bayer S, Mericske-Stern R, Jepsen S. Effect of platform switching on peri-implant bone levels: a randomized clinical trial. Clin Oral Implants Res 2011;22:1185-1192.

19. Al-Nsour MM, Chan HL, Wang HL. Effect of the platform-switching technique on preservation of peri-implant marginal bone: a systematic review. Int J Oral Maxillofac Implants 2012;27:138-145.

20. Tarnow DP, Cho SC, Wallace SS. The effect of inter-implant distance on the height of inter-implant bone crest. J Periodontol 2000;71:546-549.

21. Tarnow D, Elian N, Fletcher P, Froum S, Magner A, Cho SC, et al.. Vertical distance from the crest of bone to the height of the interproximal papilla between adjacent implants. J Periodontol 2003;74:1785-1788.

22. Linkevicius T, Puisys $A$, Steigmann $M$, Vindasiute $E$, Linkeviciene L. Influence of vertical soft tissue thickness on crestal bone changes around implants with platform switching: a comparative clinical study. Clin Implant Dent Relat Res 2015;17:1228-1236.

23. Lindhe J, Meyle J. Peri-implant diseases: Consensus Report of the Sixth European Workshop on Periodontology. J Clin Periodontol 2008;35:282-285.

24. Romanos GE, Biltucci MT, Kokaras A, Paster BJ. Bacterial composition at the implant-abutment connection under loading in vivo. Clin Implant Dent Relat Res 2016;18:138-45.

25. Li JY, Wang HL. Biomarkers associated with periimplant diseases. Implant Dent 2014;23:607-611. 